\title{
Helsetjenesten er ikke som andre tjenester
}

Er det mulig at Lewis Goldfarb, en irritert boligkjøper i Virgina, USA, er ansvarlig for den byråkratiseringen, kommersialiseringen og deprofesjonaliseringen av helsetjenesten som har foregått i store deler av den vestlige verden de siste 20-30 årene? Ja, mener Arnold S. Relman, forfatter og redaktør av The New England Journal of Medicine i perioden 1977-91. Han har analysert den amerikanske helsetjenesten i en årrekke (1-3) og er nå professor emeritus ved Harvard-universitetet. Jeg fikk anledning til å diskutere utviklingen med Relman og Marcia Angell (også hun tidligere redaktør av The New England Journal of Medicine) på et seminar i regi av Fritt Ord og New York Review of Books nylig (4). Relmans analyser var særlig spennende.

Noe av det mest interessante var det han betegnet som det avgjørende vendepunktet: Da amerikansk helsetjeneste gikk over fra å være overveiende profesjonsstyrt til å bli markedsstyrt. Relman tidfester dette til 1975, da Lewis Goldfarb gikk til sak mot staten Virgina - og vant! Historien er denne: Goldfarb ble irritert fordi alle advokatene han ba om å utføre et bestemt oppdrag i forbindelse med et huskjøp, forlangte samme betaling. Prisen de oppga, var en rådgivende minimumstakst som den statlige advokatforeningen hadde utarbeidet for standardtjenester for advokater. Goldfarb mente at slike takster i praksis hindret konkurranse og dermed var et brudd på grunnloven. Å beskytte muligheten til fri konkurranse er et sentralt element $\mathrm{i}$ amerikansk lovgivning. Goldfarb fikk til slutt gjennomslag i høyesterett for at jurister og andre tilsvarende profesjoner driver kommersiell virksomhet og at det derfor er ulovlig å hindre konkurranse ved f.eks. prissamarbeid og utarbeiding av felles takster (jf. normaltariffen).

Verken leger eller helsetjenester var nevnt i høyesterettsdommen fra 1975, men effekten på helsetjenesten ble umiddelbart synlig, ifølge Relman. Før Goldfarb-saken ble det for en lege betraktet som brudd på god legeetikk kun å tenke profitt. Den amerikanske legeforeningen (AMA) forbød, som den norske, legene å avertere for virksomheten sin, selge legemidler eller ha økonomiske interesser i f.eks. sykehus, laboratorier eller laboratorieutstyr. Etter rettssaken i 1975 advarte juristene i den amerikanske legeforeningen mot disse etiske retningslinjene fordi de mente leger og legeforeningen kunne bli domfelt for konkurransehemmende virksomhet. Retningslinjene ble derfor justert. Dermed ble synet på riktig profesjonell legeatferd endret i USA: Fra å anse fastsatte takster og ikke åpen konkurranse seg imellom som legeetisk korrekt, gikk man nå over til å se på slik atferd som uønsket monopolisering av helsetjenester.

Det springende punktet er om man tror - eller ikke tror - at konkurranse mellom dem som tilbyr en tjeneste er et gode for «kunden». Det mente amerikansk høyesterett at det var i rettssaken mellom Goldfarb og advokatforeningen i Virginia 1975. Slik sett kan Arnold Relman ha rett $\mathrm{i}$ at denne høyesterettsavgjørelsen markerer et vendepunkt. Den tradisjonelle profesjonsetikken som tidligere hadde holdt en viss kontroll på bl.a. legenes inntekter og yrkesutøvelse ble endret nærmest over natten. Helsetjenester skulle være som annen forretningsvirksomhet. Og slik ble det.
Verken jusen eller medisinen eksisterer i et politisk vakuum. En vesentlig grunn til at markedstankegangen fikk gjennomslag både i rettsapparatet og helsetjenesten, var de politiske vindene som blåste over både USA og Europa i 1980-årene: Ronald Reagan ble president i USA, Margaret Thatcher statsminister i Storbritannia og Kåre Willoch i Norge. Tiltroen til at markedskreftene og den frie konkurransen kunne bidra til vesentlig verdiskapning også i offentlig sektor var på sitt høyeste. Denne tankegangen fikk forskjellig utslag for helsepolitikken i USA og i Norge. Men fellesnevneren er at kostnadene til helsevesenet har eksplodert, at misnøyen øker og at de uløste oppgavene er flere enn noen gang $(1,5)$.

Kunne man forutsett at det å gi markedstankegang friere spillerom ikke ville være et gode for helsetjenesten - helt uavhengig av ideologisk og politisk ståsted? Ja, Kenneth Arrow gjorde nettopp det, for over 45 år siden. Han er en banebrytende økonom som fikk nobelprisen i 1972. I 1963 skrev han artikkelen Uncertainty and the welfare economics of medical care (6) - en klassiker innen helseøkonomi. Ikke bare det; den regnes som utgangspunktet for selve faget helseøkonomi. Hovedbudskapet i artikkelen er at et system basert på konkurranse og frie markedskrefter ikke vil fungere verken for pasienter eller for samfunnet som helhet. En vesentlig årsak er at et velfungerende marked fordrer symmetrisk informasjon, dvs. at alle parter har lik tilgang til informasjon. Slik er ikke situasjonen i helsevesenet. Pasientene velger heller ikke å bli syke og kommer dermed $i$ et helt spesielt avhengighetsforhold til dem som tilbyr helsetjenester. Da kan ikke et marked fungere. Arrow konkluderte med at en sterk profesjonsetikk og selvjustis blant legene, støtte og engasjement fra pårørende samt offentlig styring og kontroll - ikke av økonomien, men av innhold og kvalitet - var avgjørende for å sikre pasienter en god helsetjeneste (6).

Tidlig i 1960-årene var det lite penger å tjene på helsetjenester, og økonomer hadde minimal interesse for området. Heller ikke Kenneth Arrow. Han skrev sin artikkel på oppdrag fra Ford Foundation fordi han hadde utmerket seg som en skarp teoretiker. Han leste seg opp fra grunnen av og appliserte sin kunnskap og sitt intellekt. Det gjør artikkelen ekstra imponerende; det er vanskelig å hevde at han konkluderte ut ifra bestemte interesser. Man tar seg i å lure på om helseøkonomer og andre som gir råd om utviklingen av helsepolitikken - både i Norge og USA - faktisk har lest Arrows klassiske artikkel.

\section{Charlotte Haug}

redaktør

\section{Litteratur}

Relman AS. Medical professionalism in a commercialized health care market. JAMA 2007; 298: 2668-70.

2. Relman AS. What market values are doing to medicine. Atlantic 1992; 269: 98-102.

3. Relman AS. Shattuck Lecture - the health care industry: where is it taking us? N Engl J Med 1991; 325: 854-9

4. The hope for humanism: Within the west, beyond the west. http://fritt-ord.no/no/ nyrb/the_new_york_review_of_books/category/nyrb/ (6.6.2010).

5. Haug C. Hvor utgangspunktet er galest... Tidsskr Nor Legeforen 2009; 129: 1729. . Arrow K. Uncertainty and the welfare economics of medical care. Amer Econ Rev 1963; 53: 941-73. 